\title{
Peran Negara Dan Revolusi Sosial Dalam Pandangan Theda Scocpol
}

\author{
Anang Fajrul Ukhwaluddin ${ }^{1}$, Sultoni Fikri' ${ }^{2}$ \\ ${ }^{1}$ Fakultas Ilmu Sosial dan Ilmu Politik, Universitas Indonesia \\ ${ }^{2}$ Fakultas Hukum, Universitas Airlangga \\ Email corresponding author: sultonifikri6694@gmail.com
}

\begin{abstract}
ABSTRAK
Tulisan ini berupaya menjelaskan pandangan Theda Scocpol mengenai peran negara dan revolusi sosial. Dalam karyanya yang berjudul State and Social Revolution, ia memandang negara sebagai suatu perangkat organisasi, pengambil kebijakan dan militer yang dikelai oleh eksekutif. Kemudian Skocpol mendefenisikan revolusi sosial sebagai perubahan yang cepat dan mendasar dari masyarakat dan struktur kelas suatu negara. metode yang digunakan adalah metode studi literatur yang bersumber dari berbagai buku, jurnal ilmiah, berita dan sumber lainya yang relevan dengan topik pembahasan dan yang datanya dapat dipertanggungjawabkan. Skocpol mendorong perubahan paradigma dari Society Centre Theory ke State Centre Theory. Dari paradigma negara sebagai arena netral bagi kelompok-kelompok masyarakat dengan melihat masyarakat secara horizontal menjadi negara memiliki kuasa dan kekuatan untuk mengatur dan mengelola kehidupan masyarakatnya. Selanjutnya bagi Skocpol, revolusi sosial menekankan pada tiga hal, yaitu perubahan mendasar, terjadi pada struktur sosial dan politik secara bersamaan dan adanya perjuangan kelas yang kuat dan dominan.
\end{abstract}

Kata kunci: Negara, Revolusi Sosial, Kelas Sosial

\section{PENDAHULUAN}

Theda Skocpol adalah seorang sosiolog dan ilmuwan politik yang berkewarganegaraan Amerika Serikat. Salah satu karyanya yang cukup fenomenal yakni sebuah buku yang berjudul State and Social Revolution, buku tersebut menjelaskan dan membandingkan mengenai revolusi sosial yang terjadi di tiga negara yakni Prancis, Rusia dan China. Dalam buku tersebut Skcopol menjelaskan pemikiranya mengenai negara dan revolusi sosial yang dikembangkan dari berbagai teori-teori sosial ilmiah yang selama ini ada. Latar belakang Skocpol mengembangkan teori tersebut dikarenakan teori-teori sosial ilmiah yang ada cenderung tidak mampu menjelaskan dan menguriakan fenomena-fenomena konflik politik secara umum dan secara khusus mengenai revolusi secara utuh dan komperhensif (Skcocpol, 1979:3). Selain itu yang menjadi kelemahan dari teori atau perspektif lainnya adalah terbatasanya kemampuan dalam menganalisas suatu fenomena.

Alasan yang mendorong Skocpol menelitei Prancis, Rusia dan China adalah karena proses revolusinya memiliki kesamaan satu sama lain. Salah satu kesamaan tersebut yakni terletak pada perjuangan kelas dan politik yang berjalan dengan cukup lama (Skcocpol, 1979: 36). Ini yang kemudian menjadi hal penting dan inti dalam pemikirannya Skocpol. Dalam membangun basis argument dalam peneliteiannya Skocpol menggunakan pendekatan dan teori-teori dalam tradisi Marxis, baik ortodoks maupun neo-marxis. Juga dengan pendekatan dari Ted Gurr, Charles Tilly dan Chalmers Jhonson yang masing-masing pemikir tersebut fokus pada pendekatan plurasil, konflik politik dan konsensus nilai.

Pada proses penelitiannya Skcopol mencoba untuk keluar dari yang selama ini dilakukan para ilmuwan atau pemikir lainnya. Ketika para ilmuwan atau pemikir lainnya dalam 
melakukan peneliteian berangkat dari barat ke timur, maka Skcopol mencoba untuk membalik hal tersebut dengan memulainya dari timur ke barat. Salah satu tujuan adalah agar ketika melihat kasus yang terjadi di Timur Skocpol tidak menggunakan kacamata Barat, seperti yang lazim digunakan oleh para ilmuwan dan pemikir pada umumnya.

\section{METODE PENELITIAN}

Metode pencarian data yang digunakan dalam penelitian ini adalah dengan metode studi literatur yang bersumber dari berbagai buku, jurnal ilmiah, berita dan sumber lainya yang relevan dengan topik pembahasan dan yang datanya dapat dipertanggungjawabkan.

\section{PEMBAHASAN}

\section{Teori Negara}

Theda Skocpol memandang bahwa selama ini terjadi pengabaian terhadap teori negara, sehingga Skocpol dan beberapa ilmuwan lainnya kemudian mendorong perubahan paradigma dari Society Centre Theory ke State Centre Theory. Paradigma Society Centre Theory memandang bahwa negara sebagai sebuah arena netral bagi kelompok-kelompok masyarakat atau melihat masyarakat secara horizontal. Sedangkan State Centre Theory memandang negara secara vertikal, negara memiliki kekuasaan yang besar sehingga mampu untuk mengatur dan mengelola kehidupan masyarakat. Negara dimaknai sebagai suatu asosiasi yang memiliki kekuatan untuk memaksa dan memonopoli kekerasan.

Bagi Skocpol negara harus dilihat sebagai suatu perangkat organisasi administrasi, pengambil kebijakan dan militer yang dikepalai/kordinasi dengan baik oleh suatu otoritas eksekutif. Di sisi lain setiap negara mengambil sumber daya masyarakat dan menyebarkan sumberdaya tersebut untuk menciptakan dan mendukung organisasi pemaksaan dan organisasi administratifnya. Dalam kondisi ini negara harus dibangun dan beroperasi baik dalam konteks hubungan sosial-ekonomi yang berlandaskan kelas, ataupun konteks dinamika nasional dan internasional (Skcocpol, 1979: 26).

Negara dalam pandangan Skocpol dalam batas tertentu perlu untuk bersaing dengan kelas dominan untuk mengambil sumberdaya ekonomi bagi masyarakatnya. Dengan catatan sumberdaya ekonomi yang telah diperoleh negara sebaiknya digunakan untuk tujuan yang berbeda dengan kepentingan kelas dominan. Dan negara mempunyai dua perangkat kewajiban yang sangat mendasar yakni memelihara ketertiban dan bersaing dengan negara lain.

Posisi negara dalam mempertahankan keteraturan fisik dan perdamaian politik bertujuan untuk memperkuat konsensi terhadap tuntutan kelas bawah yang berpotensi mengorbankan kepentingan kelas dominan tetapi tidak berlawanan dengan kepentingan negara dalam menjalankan kewajibannya (mengendalikan penduduk, menarik pajak dan merekrut militer, hal ini kemungkinan terjadi ketika negara sedang berada pada posisi krisis.

\section{Revolusi Sosial}

Skocpol mendefenisikan Revolusi Sosial sebagai perubahan yang cepat dan mendasar dari masyarakat dan struktur kelas suatu negara. Revolusi tersebut bersamaan dengan terjadinya pemberontakan kelas bawah. Skocpol menambahkan meskipun sebuah revolusi yang diwarnai dengan pemberontakan berhasil dengan baik dan melibatkan pemberontak kelas bawah namun apabila tidak menyebabkan munculnya perubahan struktural maka revolusi sosial tersebut tidak dapat disebut sebagai revolusi sosial. Skocpol membedakan antara revolusi sosial dan revolusi politik, revolusi sosial bertujuan untuk melakukan perubahan terhadap struktur kelas suatu negara sedangkan revolusi politik bertujuan untuk merubah struktur negara dan revolusi politik 
tidak mampu merubah struktur sosial ini tidak dilakukan melalui konflik kelas (Skcocpol, 1979: 2).

Untuk menjelaskan pemikirannya Skocpol memberikan contoh mengenai proses industrialisasi yang dapat mengubah struktur sosial tanpa harus menimbulkan dan mengakibatkan pergolakan politik. Hal ini kemudian yang menjadi salah satu pijakan bagi Skocpol untuk mendefinisikan revolusi. Bahwa revolusi sosial merupakan fenomena perubahan yang mendasar dalam struktur sosial maupun politik yang berlangsung secara bersama-sama dan saling memperkuat satu sama lain. Perubahan tersebut berlangsung melalui konflik sosial politik yang memakan waktu cukup lama yang di dalamnya perjuangan kelas memiliki peran cukup sentral (Skcocpol, 1979: 2). Dalam defenisi tersebut Skocpol setidaknya mengemukakan tiga hal yang utama. Pertama, terjadinya perubahan yang mendasar. Kedua, perubahan tersebut terjadi pada struktur sosial dan struktur politik. Dan ketiga, terdapat perjuangan kelas yang sangat kuat dan dominan di dalamnya.

Dalam melakukan pendefinisian tersebut Skocpol memandang bahwa teori-teori sosial ilmiah tidak cukup memadai untuk digunakan dalam menjelaskan kasus revolusi, sehingga kemudian Skocpol mengkategorisasikan teori sosial ilmiah ke dalam beberapa tipe dengan tujuan untuk melihat dan membedah karakteristik dan teori-teori tersebut. Skocpol menyebutnya sebagai kategorisasi teori umum tentang revolusi (Skcocpol, 1979: 2). Skocpol kemudian mengkategorisasikan ke dalam empat kelompok utama (Skcocpol, 1979: 4).

Pertama, pengelompokan Marxis atau gagasan-gagasan dalam karya Marx. Bagi Skocpol penganut atau pengikut Marxis merupakan orang-orang yang sangat konsisten dalam memahami revolusi sosial. Marx meyakini bahwa revolusi bukan sebuah episode tertutup dari kekerasan atau konflik, tetapi sebagai sebuah gerakan kelas yang muncul dari hasil kontradiksi struktural di dalam masyarakat yang secara historis berkembang dan secara internal dilanda konflik (Skcocpol, 1979: 4). Revolusi dalam hal ini dilakukan melalui aksi kelas yang dipimpin oleh suatu kelas revolusioner yang memiliki kesadaran diri yakni golongan borjuis dalam revolusi borjuis dan kaum proletar dalam revolusi sosialis (Skcocpol, 1979: 6).

Kedua, agregat psikologi, sebuah pemikiran yang berupaya menjelaskan revolusi melalui konsep motivasi psikologi rakyat untuk melibatkan diri ke dalam kekerasan politik atau bergabung dalam gerakan oposisi (Skcocpol, 1979: 6). Teori ini dapat dilihat dalam tulisan Ted Gurr, teutama dalam karyanya yang berjudul Why Men Rebel. Bagi Gurr kekerasan politik dapat terjadi ketika banyak anggota masyarakat menjadi marah khususnya jika kondisi praktis dan kondisi budaya yang ada merangsang agregasi terhadap sasaran-sasaran politik. Gurr menambahkan bahwa orang akan menjadi marah apabila terdapat jurang pemisah antara barang-barang berharga dan kesempatan yang mereka anggap sebagai haknya, kondisi demikian oleh Gurr disebut sebagai deprivasi relatif (Gurr, 1970: 34-47). Gurr menyebutkan beberapa bentuk kekerasan politik utama yakni kekacauan (turmoil), persekongkolan dan perang saudara (internal war), revolusi menjadi bagian dari (internal war) bersama dengan terorisme kelas kakap, perang dan perang sipil. Kemarahan tersebut dalam konteks meluas dan mendasar yang tidak hanya dialami oleh rakyat tetapi juga pemimpin, calon pemimpin dan pengikutnya (Gurr, 1970: 34-47).

Ketiga, konsensus sistem atau nilai. Kelompok tersebut berupaya menjelaskan revolusi sebagi respon kekerasan dari gerakan ideologis terhadap ketimpangan yang hebat dalam sistem sosial (Skcocpol, 1979: 6). Menurut Skocpol, karya yang representative untuk mewakili kelompok ini adalah karya Chalmers Johnson yang berjudul Revolutionary Change. Revolusi dilihat berdasarkan model sistem sosial yang terkoordinasi melalui nilai. Johnson mengemukakan bahwa revolusi tidak dapat dipisahkan dari analisis terhadap masyarakat yang hidup dan masih berfungsi. Menciptakan revolusi berarti menerima kekerasan untuk mengubah sistem atau dengan kata lain revolusi adalah implementasi dari sebuah strategi kekerasan yang 
ditujukan untuk mendorong timbulnya perubahan dalam struktur sosial. Ketika revolusi tersebut berhasil maka yang dirubah adalah inti orientasi nilai masyarakat dan upaya yang harus dilakukan adalah gerakan ideologis yang berorientasi nilai yang siap menggunakan kekerasan terhadap otoritas yang ada (Skcocpol, 1979: 9).

Dengan kata lain bahwa revolusi hanya dapat terjadi ketika krisis dan krisis terjadi bila nilai dan lingkungan mengalami ketidakharmonisan yang serius, baik karena gangguan dari dalam maupun dari luar. Rovolusi yang terjadi akan menyelaraskan kembali nilai dalam sistem atau lingkungan. Teori masyarakat dan perubahan sosial Johnson pada dasarnya menempatkan orientasi nilai dan legitimasi politik sebagai uncur kunci untuk menjelaskan situasi revolusioner (Johnson, 1966: 5).

Keempat, teori konflik politik. Teori konflik politik menyatakan bahwa konflik yang terjadi antara pemerintah dengan berbagai kolompok yang terorganisir memperebutkan kekuasaan haruslah menajdi pusat perhatian dalam setiap upaya dalam menjelaskan kekerasan kolektif dan revolusi (Skcocpol, 1979: 6). Bagi Skocpol kelompok tersebut berupaya menjelaskan revolusi sebagai respon kekerasan dari gerakan ideologis terhadap ketimpangan yang hebat dalam sistem sosial (Skcocpol, 1979: 6). Karya yang kemudian menurut Skocpol representative dalam mewakili kelompok konflik politik yakni karya Charles Tilly yang berjudul From Mobilization to Revolution. Pada kelompok ini bagaimanapun ketidakpuasan rakyat mereka tidak ikut campur tangan dalam aksi politik termasuk aksi kekerasan kecuali apabila mereka menjadi bagian dari suatu kelompok yang terorganisir yang mempunyai beberapa sumberdaya (Skcocpol, 1979: 7).

Menurut Tilly, aksi-aksi yang dilakukan oleh kelompok-kelompok termobilisir adalah lebih penting dibandingkan dengan ketidakpuasan umum atau kekecewaan dari kelompokkelompok tertentu. Maka dengan demikian dapat dipahami bahwa Tilly menolak kekerasan sebagai objek analisisnya karena menurutnya kekerasan politik sesungguhnya hanya merupakan akibat dari proses normal persiangan kelompok dalam memperebutkan kekuasaan dan tujuan tertentu (Tilly, 1978: 212-213). Tilly dalam hal ini lebih tertarik untuk menempatkan aksi kolektif atau aksi sekelompok orang dalam meraih kepentingan bersama sebagai objek analisisnya (Tilly, 1978: 213). Bagi Tilly revolusi merupakan kasus khusus dari aksi kolektif di mana kelompok yang bersaing, bertujuan untuk mendapatkan kedaulatan politik tertinggi dalam masyarakat.

Dalam menganalisis mengenai kasus revolusi sosial yang terjadi di Prancis, Rusia dan China, Skocpol cenderung menggunakan perspektif Marxis dan Konflik politik. Sementara dua perspektif atau teori yang lain agregat psikologi dan konsensus sistem nilai tidak menjadi alat analisis utama dalam melihat kasus revolusi sosial di tiga negara tersebut. Dalam menggunakan perspektif Marxis Skocpol meminjam konsep hubungan kelas yang menurutnya selalu menjadi sumber potensial bagi konflik sosial dan politik (Skcocpol, 1979: 10). Sedangkan untuk teori konflik politik Skocpol meminjam konsep mengenai organisasi dan sumber daya. Menurutnya organisasi dan sumberdaya yang tersedia bagi anggota kelas berkontirbusi terhadap kesuksesan perjungan mereka (Skcocpol, 1979: 10).

Skocpol juga memasukan faktor seperti konteks internasional, perkembangan ekonomi dalam negeri dan negara-negara lain dan organisasi dari rezim lama dan baru sebagai variabel penting dalam menganalisis. Menurut Skocpol hubungan transnasional turut berperan atas timbulnya krisis revolusioner. Negara-negara secara lebih mendasar adalah organisasi yang menjadi poros untuk mengawasi territorial dan penduduknya serta melakukan persaingan militer yang aktual maupun yang potensial dengan negara lain dalam sistem internasional (Skcocpol, 1979: 18). Selain itu yang tidak kalah penting menurut Skocpol yakni terkait dengan potensi negara untuk bersifat otonom dengan arti negara memiliki potensi untuk berkehendak sesuai dengan kemauannya sendiri tanpa selalu tergantung dari kepentingan kelas tertentu. Atas 
dasar itu kemudian dalam analisisnya Skocpol menganggap perlu untuk melihat bnetuk-bentuk kelembagaan kekuasaan-kekuasaan di negara-negara agraris khusunya tiga negara yang dijadikan obyek penelitiannya (Skcocpol, 1979: 26).

Melihat dari yang disampaikan Himmelstein dan Kimmel, Skocpol memang sangat strukturalis dalam melihat kasus revolusi baik di Perancis, Rusia maupun Cina. Meskipun meminjam teori-teori Marxis dan konflik politik, namun demikian Skocpol masih tetap beranggapan bahwa keempat kelompok teori yang dipaparkan oleh Skocpol termasuk teoriteori Marxis dan konflik politik adalah masih sangat bersifat voluntaristik (Himmelstein dan Kimmel, 1981: 1148).

Skocpol beranggapan bahwa dalam memahami kasus-kasus revolusi tidak cukup hanya dengan membedah unsur-unsur voluntarism seperti persoalan ideologi, nilai dan aksi-aksi kelompok (Himmelstein dan Kimmel, 1981: 1149). Sehingga Skocpol memasukan konteks internasional dan potensi otonomi negara yang merupakan upaya Skocpol untuk mengatasi keempat kelompok teori umum tentang revolusi yang menurutnya masih bersifat voluntarist tersebut (Himmelstein dan Kimmel, 1981: 1148).

Himmelsitein dan Kimmel secara umum membagi tiga tahap revolusi sosial Skocpol. Tahapan pertama adalah runtuhnya rezim lama, tahap kedua adalah mobilisasi massa petani berdasarkan kebangkitan kelas dan tahap ketiga adalah rekonsolidasi kekuatan negara oleh elite baru (Himmelstein dan Kimmel, 1981: 1146). Tahapan pertama runtuhnya rezim lama, pada dasarnya revolusi diawali dengan lemah atau runtuhnya struktur negara. Negara pada kondisi tersebut tidak disebabkan oleh aksi-aksi revolusi dari dalam melainkan beberapa tekanan yang sifatnya struktural. Tekanan struktural adalah krisis politik karena negara yang lemah harus menghadapi kompetisi militer maupun ekonomi dengan negara-negara yang lebih kuat dalam konteks sistem politik dan ekonomi internaisonal yang tidak berimbang.

Tahap kedua kebangkitan kalangan petani. Krisis politik pada dasarnya dibutuhkan untuk sebuah revolusi, namun jika hanya krisis yang terjadi hal tersebut tidaklah cukup. Karena revolusi sosial lahir dari rangkaian kejadian krisis politik dan revolusi petani yang tersebar merata yang ditujukan kepada kelangan kelas atas. Kebangkitan petani akan terjadi ketika kelompok petani kuat dan memiliki otonomi secara ekonomo dan politik. Selain itu kebangkitan petani akan terjadi jika para tuan tanah tidak memiliki kontrol secara langsung terhadap urusan ekonomi dan politik di tingkat lokal.( Himmelstein dan Kimmel, 1981: 1147).

Terakhir pada tahap ketiga rekonsolidasi kekuatan negara. Ketika negara dalam keadaan lemah dan petani mulai bangkit dan solid maka aktivitas utama dari revolusi adalah melakukan rekonsolidasi kekuatan negara melalui kekuatan elite-elite yang selama ini tersingkirkan. Secara umum, capaian yang ingin diraih dari revolusi tersebut adalah untuk menciptakan kondisi negara yang lebih kuat, lebih birokratis lebih tersentral. Cara melakukan rekosolidasi kekuatan negara juga sangat tergantung dengan kesempatan struktural yang tersedia dalam setiap kasus (Himmelstein dan Kimmel, 1981: 1147).

\section{KESIMPULAN}

Pemikiran Skocpol berangkat dari keterbatasan teori-teori sosial ilmiah dalam menganalisis kasus-kasus revolusi di berbagai negara. Dalam melakukan peneliteian di tiga negara Prancis, Rusia dan China Skocpol mencoba menganalisis dan mengelaborasi dengan teori dan perspektif dari Marxis mengenai perjuangan kelas, agregat psikologi dari Ted Gurr, konsensus sistem atau nilai nilai dari Chalmers Johnson dan konflik politik politik dari Tilly. Tetapi Skocpol lebih deminan menggunakan teori Marxis dan konflik politik. Skocpol mendorong perubahan paradigma dari Society Centre Theory ke State Centre Theory. Dari paradigma negara sebagai arena netral bagi kelompok-kelompok masyarakat dengan melihat masyarakat 
secara horizontal menjadi negara memiliki kuasa dan kekuatan untuk mengatur dan mengelola kehidupan masyarakatnya.

Menurut Skocpol revolusi sosial merupakan perubahan yang cepat dan mendasar dari masyarakat dan struktur kelas suatu negara. Revolusi tersebut bersamaan dengan terjadinya pemberontakan kelas bawah. Skocpol kemudian menekankan pada tiga hal, perubahan mendasar, terjadi pada struktur sosial dan politik secara bersamaan dan adanya perjuangan kelas yang kuat dan dominan. Tiga tahap revolusi sosial Skocpol menurut Himmelstein dan Kimmel, runtuhnya rezim lama, mobilisasi massa petani berdasarkan kebangkitan kelas dan rekonsolidasi kekuatan negara oleh elite baru.

\section{DAFTAR PUSTAKA}

Chalmers Johnson, Revolutionary Change, Boston: Little Brown, 1966.

Charles Tilly, From Mobilization to Revolution, Reading, Mass: Addison-Wesley, 1978.

Jerome L. Himmelstein dan Michael S. Kimmel, "Review: States and Revolutions: The Implications and Limits of Skocpol's Structural Model", American Journal of Sociology, 86:5, 1981.

Ted Robert Gurr, Why Men Rebel, Pricenton, N.J: Pricenton University Press, 1970.

Theda Skocpol, Negara dan Revolusi Sosial: Suatu Analisis Komparatif tentang Perancis, Rusia dan Cina, Jakarta: Erlangga, 1979. 